Article

\title{
Enrichment of Different Plant Seeds with Zinc and Assessment of Health Risk of Zn-Fortified Sprouts Consumption
}

\author{
Renata Bączek-Kwinta ${ }^{1, *(\mathbb{D}) \text {, Agnieszka Baran }}{ }^{2}$, Magdalena Simlat ${ }^{1}$, Jakub Lang ${ }^{1,2,3}$, \\ Maciej Bieniek ${ }^{1,2,4}$ and Bartłomiej Florek ${ }^{1,2,5}$ \\ 1 Department of Plant Breeding, Physiology and Seed Science, University of Agriculture in Krakow, \\ ul. Łobzowska 24, 31-140 Krakow, Poland; magdalena.simlat@urk.edu.pl (M.S.); \\ jakub.lang@student.uj.edu.pl (J.L.); 83720@student.ump.edu.pl (M.B.); bf81763@sgh.waw.pl (B.F.) \\ 2 Department of Agricultural and Environmental Chemistry, University of Agriculture in Krakow, \\ Al. Mickiewicza 21,31-120 Cracow, Poland; agnieszka.baran@urk.edu.pl \\ 3 Department of Plant Physiology and Biochemistry, Faculty of Biochemistry, Biophysics and Biotechnology, \\ Jagiellonian University in Cracow, ul. Gronostajowa 7, 30-387 Cracow, Poland \\ 4 Faculty of Medicine, Poznan University of Medical Sciences, ul. Fredry 10, 60-780 Poznań, Poland \\ 5 Department of Economics, Warsaw School of Economics, al. Niepodległości, 02-554 Warsaw, Poland \\ * Correspondence: rrbaczek@cyf-kr.edu.pl
}

Received: 10 April 2020; Accepted: 24 June 2020; Published: 29 June 2020

\begin{abstract}
Zinc ( $\mathrm{Zn})$ is a nutrient that regulates many vital functions of the human body, hence the demand for $\mathrm{Zn}$ in the balanced daily nutrition has to be covered. Priming of seeds with $\mathrm{Zn}$ for Zn-enriched sprout production can be considered a good alternative to artificial supplementation in a modern diet. Hence, the aim of our study was to determine the exposure level of $\mathrm{Zn}$ bringing neither risk for humans nor growth inhibition of enriched broccoli, pea and sunflower sprouts. Seeds treated with $0,10,20$ and $30 \mu \mathrm{gL}^{-1} \mathrm{ZnSO}_{4}$ responded in a differentiated way to $\mathrm{Zn}$. Pea seed germination and sprout growth was diminished by $30 \mu \mathrm{g} \mathrm{mL}^{-1} \mathrm{ZnSO}_{4}$, but for sunflower sprouts this $\mathrm{Zn}$ level resulted in the highest fresh mass and largest hypocotyls. Zn content in sprouts greatly increased in a dose-dependent manner, mostly in broccoli (up to 25 times) and peas (up to 4 times), and to a lesser extent (up to $120 \%$ ) for sunflowers. Free radical scavenging activity was usually decreased. Considering the potential non-carcinogenic risk of sprouts consumption estimated by the hazard analysis, the safest exposure level for seed priming will be $10 \mu \mathrm{g} \mathrm{mL}^{-1} \mathrm{ZnSO}_{4}$. It was confirmed by random amplification of polymorphic DNA analyses indicating no DNA variations in sprouts treated with $10 \mu \mathrm{g} \mathrm{mL}^{-1} \mathrm{ZnSO}_{4}$ compared to the control.
\end{abstract}

Keywords: zinc biofortification; free-radical scavenging activity; pre-germination treatment; RAPD; sprouts

\section{Introduction}

The aim of the study was to estimate whether the enrichment of sprouts of different plant species with zinc $(\mathrm{Zn})$ via seed priming can safely increase $\mathrm{Zn}$ bioavailability in modern human diets. Seed priming with different minerals, as well as foliar spraying and fertigation is an example of agronomic treatment within biofortification methods to increase the bio-available mineral concentration in edible crops [1-3]. Zn, due to its many physiological functions in living organism is considered to be one of the crucial nutrients [4-8]. However, since it is quite common in the environment, being a constituent of many compounds and present in waste substances used in agriculture, it may accumulate in the soil [8]. Zinc is an element that regulates many vital functions of the human body as a component 
of enzymes, important for blood coagulation and factor regulating the work of many organs [9]. Therefore, the demand for $\mathrm{Zn}$ in balanced daily nutrition has to be covered, but an estimated $17.3 \%$ of the global population is at risk of inadequate zinc intake. The estimated prevalence of inadequate zinc intake ranges from $7.5 \%$ in high-income regions to $30 \%$ in South Asia [5]. Although the populations with a high standard of living in developed countries have no problem with $\mathrm{Zn}$ supply, some people need to control and supplement $\mathrm{Zn}$ in their diets. Among those are: pregnant women, patients with skin ulcers and low blood Zn levels, as well as elderly people threatened with an ophthalmological issue called macular degeneration [4]. The need for $\mathrm{Zn}$ also increases during the common cold, different seasonal flu infections and nowadays people may be willing to use over-the-counter supplements, including those with Zn, to boost immunity due to the COVID-19 pandemic [7]. People are increasingly aware of the importance of micro- and macroelements in the diet, and the demand for healthy food generates an increased supply of dietary supplements. The common access to supplements, however, is not supported by appropriate clinical control, and includes harmful ingredients or triggers unpleasant side effects and detrimental interactions with antibiotics and blood pressure drugs [6]. Therefore, we believe that sprouts enriched (fortified) with Zn can be a good, inexpensive and tasty alternative to artificial supplementation. Wheat and rice belonging to cereals have already been $\mathrm{Zn}$-fortified [1,6] as well as different legumes $[7,8]$. In our work, we enriched seeds of three species from different taxa and of different chemical composition and size to increase $\mathrm{Zn}$ content in sprouts. We have chosen peas taking into account their nutritional values as a source of protein; as well as broccoli, which is a source of anti-cancer substances [8]; and sunflower as a source of vitamin E, polyunsaturated fatty acids and isoflavones [9,10]. It is worth to noting that $\mathrm{Zn}$ is not only an essential mineral nutrient but also a heavy metal which brings potential toxicity when overdosed both to plants and humans [11]. Hence, the purpose of our research was to determine the optimal exposure level of $\mathrm{Zn}$, which would carry no risk for humans nor result in growth inhibition of the enriched sprouts. The risk may be estimated by calculating a daily dose of $\mathrm{Zn}$ uptaken with the consumed sprouts, and DNA alterations of the fortified product. That is why we determined the effect of $\mathrm{Zn}$ on the DNA markers profile of sprouts, as high accumulation of heavy metals can cause DNA damage [10,11]. We used random amplification of polymorphic DNA (RAPD) markers, a useful and powerful technique for various polymorphism analyses including genetic diversity and similarity, cultivar identification and phylogenetic analysis of many plant species [12-16]. RAPD markers are also useful for studying variability in in vitro cultures [17-21]. Some studies of the genotoxic effect of zinc using RAPD markers have also been reported [22-27]. Liu et al. [23] indicated that RAPD was more sensitive to detecting DNA variability compared to classical genotoxic tests since RAPD may detect variations that may not be finally manifested as mutations. In addition, we estimated the impact of $\mathrm{Zn}$ on the health benefits of sprouts defined as antioxidant activity, which is often taken into account in the case of such food [28-30]. The use of multiple quality indicators for assessment of zinc enrichment will offer a more effective and sustainable pathway to alleviating Zn deficiency in human diets. Moreover, the proposed combination of various indicators in the quality assessment of sprouts (biometric, chemical, physiological, genetical, nutritional and health risk analysis) is novel and protects both the plant and human health.

\section{Materials and Methods}

\subsection{Preparation of Plant Sprouts, Scheme of Experiment}

Plant material consisted of seeds recommended by manufacturers for sprout production: broccoli (Brassica oleracea var. botrytis italic), mix of cultivars (Plantico, Poland), sunflower (Helianthus annuus L.), mix of cultivars (Vilmorin, Poland) and pea (Pisum sativum L.), cv. "Szesciotygodniowa Łuskowana" seeds (Polan, Poland). At the beginning of the experiment, the batches of 960 seeds of pea and sunflower (for each replication 80 seeds), and 3600 seeds of broccoli (for each replication 300 seeds) were soaked for $24 \mathrm{~h}$ at $25 \pm 3{ }^{\circ} \mathrm{C}$ in $100 \mathrm{~mL}$ aliquots of $\mathrm{ZnSO}_{4}$ (zinc sulfate heptahydrate $\mathrm{ZnSO}_{4} 7 \mathrm{H}_{2} \mathrm{O}, \mathrm{MERCK}$ ) solutions with different concentrations of $\mathrm{Zn}$, namely $0,10,20,30 \mu \mathrm{g} \mathrm{mL}{ }^{-1}$. The concentrations were 
used according to Zou et al. [31] and in the whole paper they will be consequently termed Zn0, Zn10, Zn20 and Zn30. The imbibed seeds were washed with distilled water three times and allowed to germinate for 4 days (broccoli) and 5 days (pea, sunflower). Cultivation of sprouts of all species was carried out in triplicate, each treatment in $250 \mathrm{~mL}$ beakers at room temperature $\left(20-23{ }^{\circ} \mathrm{C}\right)$ and $12 \mathrm{~h}$ of daylight illumination and RH 50\%. Light intensity was $100 \pm 5 \mu \mathrm{mol} \mathrm{m}^{-2} \mathrm{~s}^{-1}$ photon flux density during the light period. All seed batches were viable and germinated properly, and seedlings were healthy with no necroses or any developmental aberrations.

\subsection{Biometric Measurements}

Measurements of growth parameters including: germination percentage, fresh weight of sprouts and hypocotyl length were performed according to Zou et al. [31]. The hypocotyl length was measured using the Image J image analysis program. Moreover, on the basis of the obtained data, the germination index (GI) was calculated according to the following formula:

$$
\mathrm{GI}=(\mathrm{GsLs}) /(\mathrm{GcLc}) 100 \%
$$

where Gs and Ls are the seed germination (percentage) and hypocotyl length ( $\mathrm{mm}$ ) for the sample, and Gc and Lc are the corresponding control values. GI values within the range of 90-110\% were classified as "no effect/non-toxic", GI values $<90 \%$ were classified as inhibition, and GI values $>110 \%$ were classified as stimulation [32].

\subsection{Concentration of Zinc}

Zinc concentrations in the sprouts were determined after dry digestion at the temperature of $450{ }^{\circ} \mathrm{C}$ and dissolving the ash in 1:3 $\mathrm{H}_{2} \mathrm{O}: \mathrm{HNO}_{3} \mathrm{v} / \mathrm{v}$. Zinc content in the obtained solutions was determined using ICP-OES (inductively coupled plasma optical emission spectroscopy) method on Optima 7300 DV [8]. The analytical results of the quality control samples showed a good agreement with the certified value reference material (BCR 129), Zn recovery ranges were from 88-104\%.

\subsection{Health Risk Assessment}

In the studies the health risk analysis enabled the determination of potential non-carcinogenic hazards for adult women and men from the presence of $\mathrm{Zn}$ in the samples of sprouts. Daily intake is the crucial parameter for the calculation of the real health risk value. Estimated daily intake (EDI, $\mathrm{mg} \mathrm{kg}{ }^{-1}$ body weight per day) was calculated using formula [33]:

$$
\mathrm{EDI}=\mathrm{C} \times \mathrm{E}_{\mathrm{F}} \times \mathrm{E}_{\mathrm{D}} \times \mathrm{F}_{\mathrm{IR}} / \mathrm{W}_{\mathrm{AB}} \times \mathrm{T}_{\mathrm{A}} \times 1000
$$

where: $C$ is the $\mathrm{Zn}$ concentration in sprouts $(\mathrm{mg} / \mathrm{kg}), \mathrm{E}_{\mathrm{F}}$ is the exposure frequency (365 days/year), $E_{D}$ is the exposure duration (70 years), $F_{I R}$ is the sprouts ingestion rate $(0.015 \mathrm{~kg} /$ person $/$ day $), W_{A B}$ is the average body weight $(70 \mathrm{~kg}$ for adult $)$ and $\mathrm{T}_{\mathrm{A}}$ is the average exposure time $\left(\mathrm{E}_{\mathrm{F}} \times \mathrm{E}_{\mathrm{D}}\right)$.

\section{Non-Carcinogenic Risk of Sprouts Consumption}

Potential non-carcinogenic risk connected with consumption of sprouts enriched in $\mathrm{Zn}$ was calculated by determination of the hazard quotient (HQ) values, according to formula [34]:

$$
\mathrm{HQ}=\mathrm{EDI} / \mathrm{RfD}
$$

where: $\mathrm{HQ}$ is the hazard quotient (unitless), EDI is the estimated daily intake $\left(\mathrm{mg} \mathrm{kg}^{-1}\right.$ body weight per day) and RfD is the oral reference dose value. The RfD values of $Z$ n were set to be $3.00 \times 10^{-1} \mathrm{mg} \mathrm{kg}^{-1}$ body weight per day [34]. 


\subsection{Free-Radical Scavenging Activity (FRSA)}

Samples were homogenized with a mortar and a pestle, in pre-chilled $\left(4^{\circ} \mathrm{C}\right) 50 \%(v / v)$ ethanol, in a 1:10 ratio (fresh weight of sprout sample: $\mathrm{mL}$ of ethanol). The homogenate was centrifuged (Eppendorf, $5430 \mathrm{R})$ at $7197 \times \mathrm{g}$ and $4{ }^{\circ} \mathrm{C}$ for $3 \mathrm{~min}$. The supernatant was collected and kept in a new series of test tubes on ice, in darkness. Following that, $0.01 \mathrm{mmol} \mathrm{dm}^{-3} \mathrm{DPPH}$ (1,1-diphenenyl-1-picrylhydrazyl; Sigma-Aldrich) dissolved in $80 \%$ ethanol was used for spectrophotometric analyses (4050 Ultrospec II, LKB Biochrom). Next, $0.2 \mathrm{~mL}$ of plant supernatant was mixed with $0.8 \mathrm{~mL}$ of DPPH and the kinetics of total DPPH scavenging was performed for $5 \mathrm{~min}$, at $\lambda=517 \mathrm{~nm}$. The results were expressed as $\Delta$ of absorbance $[29,35]$.

\subsection{DNA Analysis}

For DNA isolation the sprouts were ground in liquid nitrogen using mortar and pestle, and $100 \mathrm{mg}$ of the obtained tissue powder was transferred into a $1.5 \mathrm{~mL}$ Eppendorf tube. DNA was isolated using Genomic Mini AX Plant Kit (AA Biotechnology), following the manufacturer's instructions. The DNA quantity and quality were assessed on the basis of the $\mathrm{A}_{260}$ measurement (spectrophotometer NanoDrop 2000c) and standard agarose electrophoresis. For genetic variability analysis 10 RAPD primers (OPERON) were used: OPR-01-TGCGGGTCCT, OPR-02-CACAGCT GCC, OPR-03-ACACAGAGGG, OPR-04-CCCGTAGCAC, OPR-05-GACCTAGTGG, OPR-06-GTCT ACGGCA. OPA-03-AGTCAGCCAC, OPA-11-CAATCGCCGT, OPA-13-CAGCACCCAC, OPA-19CAAACGTCGG. Amplification, visualization and analysis of obtained DNA fragments were performed according to Simlat et al. [36].

\subsection{Statistical Analysis}

All results were reported as mean \pm standard deviation. The results were verified statistically using one-factor ANOVA and Tukey's test at the significance level $\alpha=0.05$. A Microsoft Excel 2007 spreadsheet and the Statistica 12.0 package were used for the analysis and presentation of the obtained results.

\section{Results}

\subsection{Effect of Zn Priming of Seeds on Sprouts Growth Parameters and Zn Content, and Health Risk Assessment}

Table 1 shows the results of growth parameters measured for the sprouts grown from seeds treated with various exposure levels of $\mathrm{Zn}$. The three plant species used in the experiment showed diverse reaction to Zn. Zn10 solutions caused the highest significant increase in hypocotyl length and in fresh mass in broccoli and peas. The highest level of $\mathrm{Zn}(\mathrm{Zn} 30)$ reduced growth of pea sprouts: a decrease in germination and in fresh weight was about 1.2-1.4-fold, respectively. On the other hand, Zn30 resulted in the highest fresh mass and hypocotyl length of sunflower sprouts. The germination index (GI), which comprises both germinability and the length of sprouts, allowed depiction of the results in a similar way. Generally, we found a stimulating effect on sprout growth and development (GI >110\%) for broccoli (all exposure levels of $\mathrm{Zn}$ ) and for peas (Zn10 and Zn20). Zn caused neither inhibition nor stimulation of GI (GI 90-110\%) of sunflowers. GI for peas confirmed the growth inhibition by Zn30 (GI $<90 \%)$.

As shown in Table 2, the applied exposure levels of $\mathrm{Zn}$ had significant effects on its content in sprouts. In the respective controls it was 46.3 (broccoli), 67.5 (sunflower) and 45.4 (pea), while after Zn priming it ranged from 480-1167 (broccoli), 71.1-80.8 (sunflower) and 92.4-193 (pea), namely it was 10-25, 1.1-1.2 and 2.1-4.3 times higher, respectively. The estimated daily intake (EDI) values of $\mathrm{Zn}$ for adults considering typical intake of sprouts are presented in Table 2. The acceptable daily intake (ADI) for $\mathrm{Zn}$ is equal to $11 \mathrm{mg}$ (man) and $8 \mathrm{mg}$ (woman) $\mathrm{kg}^{-1}$ day $^{-1}$. Considering the statistical consumption, estimated daily intake (EDI) values did not exceed the acceptable daily intake (ADI) for all sprouts (Table 2). Corresponding with the Zn content, the highest EDI value was calculated 
for the broccoli sprouts, next for pea sprouts and the lowest for sunflower sprouts. Based on the EDI, the hazard quotient (HQ) values were calculated for analyzed sprouts (Table 2). According to Gruszewska-Kossowska and Baran [33], the risk levels can be stated as no risk $(\mathrm{HQ}<0.1)$ in the case of consumption of sunflower sprouts (irrespective of the exposure levels of Zn), while for pea sprouts for Zn0 and Zn10, but for broccoli sprouts only without Zn priming (Zn0, Table 2). Low risk $(0.1<\mathrm{HQ}<1)$ was found for consumption of pea sprouts (Zn20 and Zn30) and all Zn-enriched broccoli sprouts. However, HQ values for Zn20 and Zn30 broccoli sprouts were close to 1, suggesting a high risk associated with the consumption of these sprouts.

Table 1. Growth parameters of sprouts obtained after treatment with different doses of $\mathrm{Zn}$. The measurements were performed after 4 days (broccoli) and 5 days (pea, sunflower) of germination. Means \pm SD from $n=3$ (one replication consisted of 80 seeds for peas and sunflowers, and 300 seeds for broccoli).

\begin{tabular}{cccccc}
\hline Species & $\begin{array}{c}\text { Exposure Level of } \\
\text { Zn } \boldsymbol{\mu g} \cdot \mathbf{m L}^{-1}\end{array}$ & Germination \% & Fresh Mass g & $\begin{array}{c}\text { Hypocotyl } \\
\text { Length } \mathbf{~ m m}\end{array}$ & $\begin{array}{c}\text { Germination } \\
\text { Index \% }\end{array}$ \\
\hline \multirow{3}{*}{ Broccoli } & 0 & $85 \pm 5 \mathrm{a} *$ & $5.68 \pm 0.8 \mathrm{ab}$ & $12.22 \pm 1.0 \mathrm{a}$ & - \\
& 10 & $87 \pm 7 \mathrm{a}$ & $7.52 \pm 1.2 \mathrm{a}$ & $15.84 \pm 2.9 \mathrm{a}$ & $123 \pm 5.0 \mathrm{a}$ \\
& 20 & $80 \pm 5 \mathrm{a}$ & $5.18 \pm 2.1 \mathrm{~b}$ & $14.72 \pm 1.8 \mathrm{a}$ & $122 \pm 18 \mathrm{a}$ \\
& 30 & $85 \pm 5 \mathrm{a}$ & $6.89 \pm 1.9 \mathrm{a}$ & $14.68 \pm 1.7 \mathrm{a}$ & $120 \pm 20 \mathrm{a}$ \\
\hline \multirow{3}{*}{ Sunflower } & 0 & $64 \pm 6 \mathrm{a}$ & $8.64 \pm 0.3 \mathrm{a}$ & $17.65 \pm 0.9 \mathrm{a}$ & - \\
& 10 & $72 \pm 7 \mathrm{a}$ & $7.89 \pm 1.5 \mathrm{a}$ & $17.39 \pm 1.6 \mathrm{a}$ & $105 \pm 11 \mathrm{a}$ \\
& 20 & $68 \pm 4 \mathrm{a}$ & $8.29 \pm 1.0 \mathrm{a}$ & $15.60 \pm 1.6 \mathrm{a}$ & $96 \pm 2 \mathrm{a}$ \\
& 30 & $66 \pm 3 \mathrm{a}$ & $9.50 \pm 1.6 \mathrm{a}$ & $17.93 \pm 3.1 \mathrm{a}$ & $105 \pm 7 \mathrm{a}$ \\
\hline \multirow{5}{*}{ Pea } & 0 & $74 \pm 5 \mathrm{ab}$ & $34.54 \pm 3.3 \mathrm{~b}$ & $2.08 \pm 0.1 \mathrm{bc}$ & - \\
& 10 & $85 \pm 1 \mathrm{a}$ & $46.65 \pm 4.2 \mathrm{a}$ & $2.78 \pm 0.4 \mathrm{a}$ & $154 \pm 19 \mathrm{a}$ \\
& 20 & $83 \pm 1 \mathrm{a}$ & $39.71 \pm 2.9 \mathrm{ab}$ & $2.41 \pm 0.2 \mathrm{ab}$ & $130 \pm 11 \mathrm{ab}$ \\
\hline
\end{tabular}

* Means followed by the different letters in line indicate significant differences at $\alpha \leq 0.05$ according to the $t$-Tukey test within the species (ANOVA at $\mathrm{p}<0.05$ ).

Table 2. Zn content in sprouts, health risk assessment (EDI, HQ) and free-radical scavenging activity (FRSA). The measurements were performed after 4 days (broccoli) and 5 days (pea, sunflower) of germination. Means \pm SD from $n=3$ for Zn content, for EDI and HQ one replication consisted of 80 seeds for pea and sunflower, and 300 seeds for broccoli. For FRSA, means \pm SD from 3 biological replicates from 3 experiments and 3 instrumental replications are presented.

\begin{tabular}{|c|c|c|c|c|c|}
\hline Species & $\begin{array}{l}\text { Exposure Level } \\
\text { of } \mathrm{Zn} \mu \mathrm{g} \mathrm{mL^{-1 }}\end{array}$ & $\begin{array}{l}\text { Zn Content } \\
\mathrm{mg} \mathrm{kg}^{-1} \mathrm{dw}\end{array}$ & $\begin{array}{c}\text { EDI of Zn mg } \\
\text { day }^{-1}\end{array}$ & HQ & $\begin{array}{c}\text { FRSA } \Delta \text { A517 } \mathrm{g}^{-1} \\
\mathrm{dw}\end{array}$ \\
\hline \multirow{4}{*}{ Broccoli } & 0 & $46.3 \pm 12 \mathrm{~d}^{*}$ & $0.010 \pm 0.003 \mathrm{~d}$ & $0.033 \pm 0.009 \mathrm{~d}$ & $0.022 \pm 0.000 \mathrm{a}$ \\
\hline & 10 & $480 \pm 24 \mathrm{c}$ & $0.103 \pm 0.005 c$ & $0.343 \pm 0.018 c$ & $0.016 \pm 0.003 b$ \\
\hline & 20 & $940 \pm 39 b$ & $0.196 \pm 0.008 b$ & $0.653 \pm 0.028 b$ & $0.012 \pm 0.002 \mathrm{~b}$ \\
\hline & 30 & $1167 \pm 9 a$ & $0.250 \pm 0.002 \mathrm{a}$ & $0.834 \pm 0.007 \mathrm{a}$ & $0.015 \pm 0.003 \mathrm{~b}$ \\
\hline \multirow{4}{*}{ Sunflower } & 0 & $67.5 \pm 1.5 c$ & $0.014 \pm 0.002 c$ & $0.048 \pm 0.001 \mathrm{c}$ & $0.015 \pm 0.002 b$ \\
\hline & 10 & $71.1 \pm 1.5 c$ & $0.015 \pm 0.003 c$ & $0.051 \pm 0.002 \mathrm{c}$ & $0.012 \pm 0.002 b$ \\
\hline & 20 & $76.6 \pm 1.2 \mathrm{~b}$ & $0.016 \pm 0.002 b$ & $0.055 \pm 0.001 b$ & $0.022 \pm 0.002 \mathrm{a}$ \\
\hline & 30 & $80.8 \pm 2.1 \mathrm{a}$ & $0.017 \pm 0.004 \mathrm{a}$ & $0.058 \pm 0.003 a$ & $0.013 \pm 0.001 \mathrm{~b}$ \\
\hline \multirow{4}{*}{ Pea } & 0 & $45.4 \pm 1.7 \mathrm{~d}$ & $0.010 \pm 0.01 \mathrm{c}$ & $0.032 \pm 0.001 \mathrm{~d}$ & $0.00136 \pm 0.0000 \mathrm{a}$ \\
\hline & 10 & $92.4 \pm 10 \mathrm{c}$ & $0.020 \pm 0.24 b$ & $0.066 \pm 0.011 \mathrm{c}$ & $0.00083 \pm 0.0001 b$ \\
\hline & 20 & $157 \pm 4.1 \mathrm{~b}$ & $0.034 \pm 0.06 a$ & $0.112 \pm 0.003 \mathrm{~b}$ & $0.00064 \pm 0.0001 b$ \\
\hline & 30 & $193 \pm 7.0 \mathrm{a}$ & $0.040 \pm 0.11 \mathrm{a}$ & $0.138 \pm 0.005 a$ & $0.00063 \pm 0.0002 b$ \\
\hline
\end{tabular}

* Means followed by the different letters in line indicate significant differences at $\alpha \leq 0.05$ according to the $t$-Tukey test within the species (ANOVA at $\mathrm{p}<0.05$ ). 


\subsection{Free-Radical Scavenging Activity (FRSA)}

$\mathrm{Zn}$ affected free-radical scavenging activity (FRSA) of sprouts of all studied species (Table 2). In the case of broccoli and peas the FRSA values were decreased by $\mathrm{Zn}$ to a similar extent. In the case of sunflowers, FRSA unexpectedly increased under the influence of Zn20 only. The comparison between the species revealed that the average FRSA was similar in sunflowers and broccoli, while in the case of peas was an order of magnitude lower.

\subsection{Effect of Zn Priming of Seeds on Sprouts DNA Variability}

All 10 decamer primers used in this study produced clearly identifiable bands in broccoli and pea samples and were used for further analysis. In the case of sunflower samples, two of the primers did not amplify any PCR product. Consequently, the total number of the produced scorable bands was 96 and 95 for broccoli and peas, respectively, and 79 for sunflowers. However, the number of polymorphic bands was very low and ranged from 3 for sunflowers to 30 for peas (Table 3).

Table 3. Total number of fragments and number of polymorphic fragments generated by random amplification of polymorphic DNA (RAPD) primers. Sprouts were obtained via enrichment of seeds with Zn0, Zn10, Zn20 and Zn30.

\begin{tabular}{|c|c|c|c|c|c|c|c|c|c|}
\hline \multirow{2}{*}{ Primer $5^{\prime} \rightarrow 3^{\prime}$} & \multicolumn{3}{|c|}{ Number of Total Bands } & \multicolumn{3}{|c|}{ Number of Polymorphic Bands } & \multicolumn{3}{|c|}{ Polymorphism (\%) } \\
\hline & Broccoli & Sunflower & Pea & Broccoli & Sunflower & Pea & Broccoli & Sunflower & Pea \\
\hline OPR-01 & 10 & 7 & 10 & 0 & 0 & 5 & 0.0 & 0 & 50.0 \\
\hline OPR-03 & 11 & 10 & 9 & 3 & 1 & 1 & 27.3 & 6.3 & 11.1 \\
\hline OPR-04 & 9 & 14 & 0 & 1 & 0 & 0 & 11.1 & 0 & 0 \\
\hline OPR-05 & 9 & 13 & 7 & 0 & 1 & 2 & 0.0 & 7.7 & 28.6 \\
\hline OPA-11 & 8 & 11 & 16 & 3 & 0 & 3 & 37.5 & 0 & 18.6 \\
\hline OPA-13 & 10 & 5 & 17 & 0 & 0 & 3 & 0.0 & 0 & 17.6 \\
\hline OPA-19 & 9 & 10 & 13 & 6 & 1 & 11 & 66.7 & 10.0 & 84.6 \\
\hline Total & 96 & 79 & 95 & 17 & 3 & 30 & - & - & - \\
\hline $\begin{array}{l}\text { Average/ } \\
\text { primer }\end{array}$ & 9.6 & 7.9 & 9.5 & 1.7 & 0.3 & 3 & 22.5 & 2.4 & 26.05 \\
\hline
\end{tabular}

The genetic matrix generated on the basis of Jaccard similarity coefficient revealed high genetic similarity between tested samples of all species. It ranged from 0.853 to 0.946 for broccoli, from 0.953 to 1.000 for sunflowers and from 0.685 to 0.944 for peas (Table 4). Zn-enriched sprouts of broccoli had a very similar profile of DNA fragments to the control $(\mathrm{Zn} 0)$. The lowest variation was observed for the DNA of sprouts treated with $Z n 20$. The constructed genetic similarity dendrogram therefore allowed the grouping of $\mathrm{Zn} 0$ and $\mathrm{Zn} 20$ into one cluster. Similarly, pea sprouts fortified with $\mathrm{Zn} 20$ showed the smallest polymorphism of DNA compared to $\mathrm{Zn} 0$ and they were also grouped into a single cluster on the dendrogram. For sunflower, on the other hand, Zn10 and Zn20 interacted in an identical manner to the DNA of treated sprouts and both were included in one closest cluster together with $\mathrm{Zn} 0$. Of all species, Zn30 showed the greatest influence on DNA variability. Such sprouts were genetically the most distant from $\mathrm{Zn} 0$ (Figure 1).

Table 4. Similarity matrix of broccoli, sunflower and pea samples generated on the basis of RAPD analysis using Jaccard similarity coefficient. Sprouts of all species were obtained via enrichment of seeds with Zn0, Zn10, Zn20 and Zn30.

\begin{tabular}{cccccc}
\hline Species & Exposure Level of Zn $\mu \mathrm{g} \mathrm{mL} \mathbf{~}^{-1}$ & Zn0 & Zn10 & Zn20 & Zn30 \\
\hline \multirow{4}{*}{ Broccoli } & Zn0 & 1.000 & & & \\
& Zn10 & 0.914 & 1.000 & & \\
Zn20 & 0.946 & 0.944 & 1.000 & \\
\hline
\end{tabular}


Table 4. Cont

\begin{tabular}{cccccc}
\hline Species & Exposure Level of Zn $\boldsymbol{\mu g} \mathbf{~ m L}^{-1}$ & Zn0 & Zn10 & Zn20 & Zn30 \\
\hline \multirow{4}{*}{ Sunflower } & Zn0 & 1.000 & & & \\
& Zn10 & 0.964 & 1.000 & & \\
Zn20 & Zn30 & 0.964 & 1.000 & 1.000 & \\
Pea & Zn0 & 0.953 & 0.964 & 0.964 & 1.000 \\
& Zn10 & 1.000 & & & \\
& Zn20 & 0.912 & 1.000 & & \\
\hline
\end{tabular}

A)

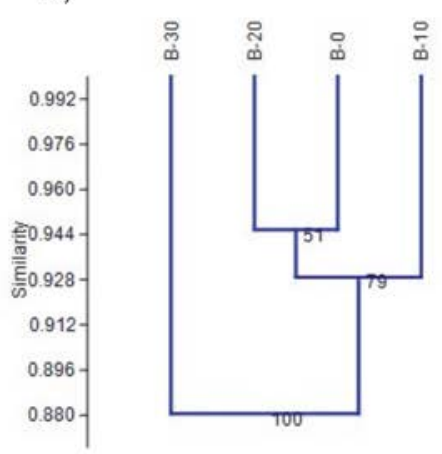

B)

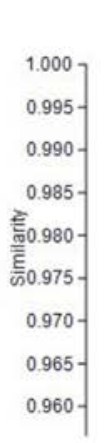

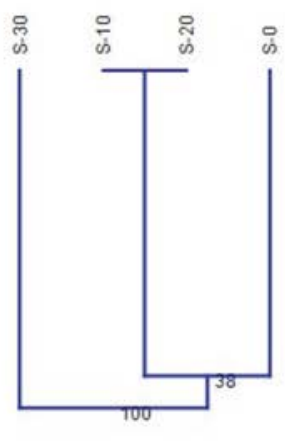

C)

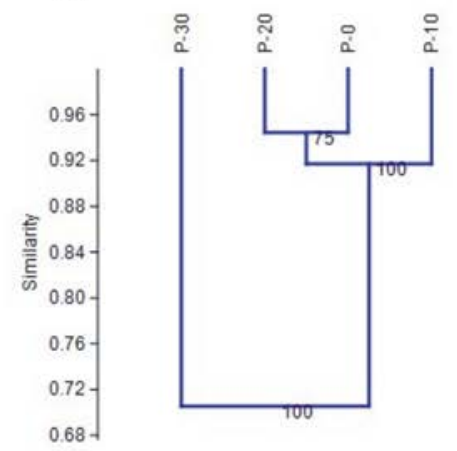

Figure 1. Dendrogram of the studied broccoli (A), sunflower $(\mathbf{B})$ and pea $(\mathbf{C})$ samples, constructed with the Jaccard similarity coefficient using UPGMA cluster analysis based on the RAPD data (cophenetic correlation for broccoli $r=0.855$, for sunflower $r=0.991$, for pea $r=9883$ ). Sprouts of all species were obtained via enrichment of seeds with Zn0, Zn10, Zn20 and Zn30.

\section{Discussion}

As various sprouts contain many phytochemicals, so the pro-health impacts of sprouts have already been the focus of different studies [16,29,30,37]. Plants eaten raw are the main sources of dietary antioxidants such as polyphenols, vitamins $C$ and $E$, carotenoids, phytates, thiocyanates, indols and various minerals with antioxidant properties, which play a significant role in the reduction of human metabolic diseases, hence the public in high- and some middle-income countries are interested in the antioxidant properties of such foods and their influence on human health [37-42].

In the present study, seed germination was unaffected or stimulated by $\mathrm{Zn}$, and the fresh weight and hypocotyl length of sprouts were generally higher due to Zn application than the control. The biomass was stimulated by Zn10. In the studies of Zou et al. [31] it was found that zinc biofortification causes high accumulation of this metal in sprouts. It is commonly known that $\mathrm{Zn}$ is essential for organism growth but is toxic in excess, and different plants may have different sensitivities to $\mathrm{Zn}$ [9]. The $\mathrm{Zn}$ concentration in leaf tissue is sufficient or normal if it lies between $25-150 \mathrm{mg} \mathrm{kg}^{-1}$ and is excessive or toxic at $300 \mathrm{mg} \mathrm{kg}^{-1}$ [8]. In our study, we noticed very high concentrations of zinc, especially in the case of broccoli sprouts. Cruz et al. [43] has shown that such differences at the germination stage can be explained by different seed sizes-Larger seeds have less surface area in relation to their volume, so they have increased protection against exposure to pollutants. The size of the seeds used in the study was in the following order: sunflower $>$ pea $>$ broccoli. Moreover, sunflower seeds have hard seed coats, which might have additionally affected the results preventing $\mathrm{Zn}$ uptake by germinating seeds. It could probably change with different times of exposure to $\mathrm{Zn}$, hence sunflower and pea seeds should be imbibed longer than those of broccoli.

Based on $\mathrm{Zn}$ accumulation and the HQ values, broccoli sprouts ( $\mathrm{Zn20}$ and $\mathrm{Zn30)}$ may cause health risks, especially in the case of consumption of other Zn sources, or Zn-enriched beverages. 
Due to the fact that sprouts have become essential components of the human diet, and at the same time, important sources of different nutrients, this research subject must be regarded as fully justified. Therefore, seed enrichment with $\mathrm{Zn}$ should be carried out carefully to avoid the potential health risk of Zn toxicity of sprouts.

We assumed that toxicity of $\mathrm{Zn}$ is related to DNA variation of $\mathrm{Zn}$-enriched sprouts. In our research, the lowest levels of DNA variability, based on RAPD markers, were noticed when Zn10 and Zn20 were used for seed priming. The same relation was observed in all tested species. However, the highest concentration of Zn (Zn30) applied in our study, could be a source of DNA variations in Zn-enriched sprouts, irrespectively of the species. Our result is in agreement with Cenkci et al. [25]. In their research, DNA damage in beans increased with an increase in concentrations of toxic chemicals, and among the others, also Zn. Nevertheless, observed in our research, the effect of Zn on DNA of sprouts of broccoli, sunflowers and peas was not high, since the lowest similarity coefficient detected for pea sprouts treated with $\mathrm{Zn} 30$ equals 0.685 .

In addition to examining potential harmfulness what is worth estimating is the health-promoting effect measured as the ability of the sprouts' extracts to scavenge free radicals $[29,30,35]$. Interestingly, FRSA values showed a downward trend under the influence of $\mathrm{Zn}$ in 8 of 9 studied cases. Therefore, the improvement in antioxidant quality of sprouts has not been obtained, except with sunflower sprouts treated with Zn20. The mechanism of Zn uptake and Zn physiological mode of action should be analyzed. $\mathrm{Zn}$ is uptaken as a free ion and translocated within plant tissues by different cation-specific transporters [44]. It performs many physiological functions. In terms of oxidative stress and antioxidant response, it is a constituent of $\mathrm{Cu} / \mathrm{Zn} \mathrm{SOD}$, the scavenging enzyme for superoxide anion, and recently it has been shown that $\mathrm{Zn}$ activates the hydroquinone groups of flavonoids, producing another protection against superoxides that mimic SOD [45]. It is commonly known that sprouts are rich in flavonoids $[28,29,42,46]$. Hence, the interaction of $\mathrm{Zn}$ and natural metabolites of sprouts might have decreased superoxide amounts generated by the young plantlets, which was reflected in the FRSA assay.

In the case of sunflowers, however, FRSA was increased by Zn20. We suppose that the explanation lies in the biometric features of these sprouts. As they developed the shortest hypocotyl within all sunflower sprouts at a relatively high mass, we suppose that they contained more cells which were not elongated, than the other sprouts. Therefore, the pool of antioxidants, whose activity is reflected by FRSA measurement, was concentrated in these tissues. It happens that heavy metals' impacts on plants is not dose-dependent (own experiment, data not shown). Why Zn20 triggered diminished GI, at the moment remains unclear.

While analyzing the differences in FRSA between the studied species, it can be assumed that they are determined by the different chemical composition of seeds. Peas accumulate large amounts of storage proteins, the other two mostly fats. Perhaps some proteins adsorb low-molecular antioxidants that remain on their surfaces in the sediment, while in the FRSA method the supernatant is tested. A similar effect was obtained by Baczek-Kwinta and Sala [29] who compared, e.g., alfalfa, belonging to the same botanical family as pea, and radish, a member of Brassicaceae, to which broccoli belongs. The antioxidant activity measured with two methods (FRSA and FRAP) of alfalfa sprouts was lower than that of radish sprouts. However, the alfalfa antioxidant activity was prolonged in time [29], hence the interspecific differences in antioxidant activity should not be considered with priority.

Zou et al. [31] proposed Zn20 as a safe exposure level for soybean sprouts. Based on (i) the estimated potential consumption of $\mathrm{Zn}$ as a form of $\mathrm{Zn}$-enriched sprouts, (ii) the calculated health risk revealing that Zn20 and Zn30 may lead to Zn toxicity, and (iii) antiradical activity which was not increased by Zn, the safest level for Zn priming of broccoli, pea and sunflower seeds is Zn10. In our opinion, this level is safe to the consumers, including those who are on medications such as antibiotics or antihypertensive drugs, which can interact with diet Zn [6,47].

Further study on the subject should consider intraspecific differentiation to choose the genotypes that are best at accumulating $\mathrm{Zn}$, with no health risk for consumers. On the other hand, as the 
seed volume to seed coat area can affect $\mathrm{Zn}$ uptake, this should be also taken into account while comparing seeds of different species. Last but not least, different plants may be equipped with different Zn-transporting proteins [48], hence further research can also be performed within the molecular background of effective and consumer-safe seed priming with $\mathrm{Zn}$.

\section{Conclusions}

Our results indicated that $\mathrm{Zn}$ used for enrichment of broccoli, pea and sunflower sprouts diminished FRSA values in 8 of 9 cases according to the respective controls ( $\mathrm{Zn} 0$ ). Moreover, $\mathrm{Zn}$ was a source of DNA variation measured by RAPD. However, the DNA variation depended mostly on the concentration of $\mathrm{Zn}$. Lower $\mathrm{Zn}$ exposure levels such as $\mathrm{Zn10}$ and $\mathrm{Zn} 20$ were safer for plant DNA than $\mathrm{Zn30.} \mathrm{Considering} \mathrm{the} \mathrm{potential} \mathrm{non-carcinogenic} \mathrm{risk} \mathrm{of} \mathrm{sprout} \mathrm{consumption} \mathrm{measured} \mathrm{by} \mathrm{HQ,}$ the safest concentration for seed priming will be Zn10. The dose also did not diminish, and even increased, the germinability index, indicating improved sprouts condition.

Author Contributions: Conceptualization, R.B.-K., A.B. and M.S.; software, R.B.-K., A.B., M.S., J.L., M.B. and B.F.; validation, R.B.-K., A.B. and M.S.; formal analysis, R.B.-K., A.B. and M.S.; investigation, R.B.-K., A.B., M.S., J.L., M.B. and B.F.; resources, R.B.-K., A.B., M.S., J.L., M.B. and B.F.; data curation, R.B.-K., A.B., M.S., J.L., M.B. and B.F.; writing-Original draft preparation, A.B., R.B.-K., M.S., J.L., M.B. and B.F.; writing-Review and editing, R.B.-K., A.B., M.S., J.L.; visualization, R.B.-K., A.B. and M.S.; supervision, R.B.-K., A.B. and M.S.; project administration, R.B.-K.; funding acquisition, R.B.-K., A.B., M.S. All authors have read and agreed to the published version of the manuscript.

Funding: The study was supported by the University of Agriculture in Cracow, DS 3145 and 2020 SUB donation.

Acknowledgments: The authors would like to thank the five reviewers whose deep and thorough remarks helped us to improve our manuscript. We are also indebted to Karolina Rybicka for her valuable linguistic comments.

Conflicts of Interest: The authors declare no conflict of interest.

\section{References}

1. Sabatino, L.; Ntatsi, G.; Iapichino, G.; D'Anna, F.; de Pasquale, C. Effect of selenium enrichment and type of application on yield, functional quality and mineral composition of curly endive grown in a hydroponic system. Agronomy 2019, 9, 207. [CrossRef]

2. Sabatino, L.; D'Anna, F.; Iapichino, G.; Moncada, A.; D'Anna, E.; De Pasquale, C. Interactive effects of genotype and molybdenum supply on yield and overall fruit quality of tomato. Front. Plant Sci. 2019, 9, 1922. [CrossRef] [PubMed]

3. Pannico, A.; El-Nakhel, C.; Graziani, G.; Kyriacou, M.C.; Giordano, M.; Soteriou, G.A.; Zarrelli, A.; Ritieni, A.; De Pascale, S.; Rouphael, Y. Selenium Biofortification Impacts the Nutritive Value, Polyphenolic Content, and Bioactive Constitution of Variable Microgreens Genotypes. Antioxidants 2020, 9, 272. [CrossRef] [PubMed]

4. The Age-Related Eye Disease Study 2 (AREDS2) Research Group. Lutein + zeaxanthin and omega-3 fatty acids for age-related macular degeneration: The Age-Related Eye Disease Study 2 (AREDS2) randomized clinical trial. JAMA 2013, 309, 2005-2015. [CrossRef] [PubMed]

5. Wessells, K.R.; Brown, K.U. Estimating the Global Prevalence of Zinc Deficiency: Results Based on Zinc Availability in National Food Supplies and the Prevalence of Stunting. PLoS ONE 2012, 7, e50568. [CrossRef]

6. Maret, W.; Sandstead, H.H. Zinc requirements and the risks and benefits of zinc supplementation. J. Trace Elem. Med. Biol. 2006, 20, 3-18. [CrossRef]

7. Hulisz, D. Efficacy of zinc against common cold viruses: An overview. J. Am. Pharm. Assoc. 2004, 44, 594-603. [CrossRef]

8. Baran, A. Assessment of Zea mays sensitivity to toxic content of zinc in soil. Pol. J. Environ. Stud. 2013, 22, 77-83.

9. Cakmak, I. Enrichment of cereal grains with zinc: Agronomic or genetic biofortification. Plant Soil. 2008, 302, 1-17. [CrossRef]

10. Dutta, S.; Mitra, M.; Agarwal, P.; Mahapatra, K.; De, S. Oxidative and genotoxic damages in plants in response to heavy metal stress and maintenance of genome stability. Plant Signal. Behav. 2018, 13, e1460048. [CrossRef] 
11. Bolukbasi, E.; Karakas, M. Effect of zinc heavy metal on stress-related genes in tomato (Solanum lycopericum L.) plants. Int. J. Environ. Agric. Biotechnol. 2019, 4, 1211-1216. [CrossRef]

12. Khanuja, S.; Shasany, A.; Srivastava, A.; Kumar, S. Assessment of genetic relationships in Mentha species. Euphytica 2000, 111, 121-125. [CrossRef]

13. Besnard, G.; Breton, C.; Baradat, P.; Khadari, B.; Bervillé, A. Cultivar identification in olive based on RAPD markers. J. Am. Soc. Hort. Sci. 2001, 126, 668-675. [CrossRef]

14. Lisek, A.; Rozpara, E. Identification of pear cultivars with RAPD and ISSR markers. J. Fruit Ornam. Plant Res. 2010, 18, 17-22.

15. Okoń, S.; Paczos-Grzęda, E.; Łoboda, M.; Sugier, D. Identification of genetic diversity among Arnica montana L. genotypes using RAPD markers. Acta Sci. Pol. Hortorum Cultus 2014, 13, 63-71.

16. Gajewski, M.; Danilcenko, H.; Szymczak, P.; Seroczyńska, A.; Radzianowska, J. Quality characteristics of fresh plant sprouts and after their shorts term storage. Veg. Crops Res. Bull. 2008, 68, 155. [CrossRef]

17. Rani, V.; Parida, A.; Raina, S.N. Random amplified polymorphic DNA (RAPD) markers for genetic analysis in micropropagated plants of Populus deltoids Marsh. Plant Cell Rep. 1995, 14, 459-462. [CrossRef]

18. Tawar, P.N.; Sawant, R.A.; Dalvi, S.G.; Nikam, A.A.; Kawar, P.G.; Devarumath, R.M. An assessment of somaclonal variation in micropropagated plants of sugarcane by RAPD markers. Sugar Tech 2008, 10, 124-127. [CrossRef]

19. Minano, H.S.; Gonzalez-Benito, E.; Martin, C. Molecular characterization and analysis of somaclonal variation in chrysanthemum cultivars using RAPD markers. Sci. Hortic. 2009, 122, 238-243. [CrossRef]

20. Cuesta, C.; Ordas, R.J.; Rodriguez, A.; Fernandez, B. PCR based molecular markers for assessment of somaclonal variation in Pinus pinea clones micropropagated in vitro. Biol. Plant. 2010, 54, 435-442. [CrossRef]

21. Ptak, A.; Simlat, M.; Kwiecień, M.; Laurain-Mattar, D. Leucojum aestivum plants propagated in in vitro bioreactor culture and on solid media containing cytokinins. Eng. Life Sci. 2013, 13, 261-270. [CrossRef]

22. De Wolf, H.; Blust, R.; Backeljau, T. The use of RAPD in ecotoxicology. Mutat. Res. Rev. Mutat. 2004, 566, 249-262. [CrossRef] [PubMed]

23. Liu, W.; Yang, Y.S.; Li, P.J.; Zhou, Q.X.; Xie, L.J.; Han, Y.P. Risk assessment of cadmium-contaminated soil on plant DNA damage using RAPD and physiological indices. J. Hazard. Mater. 2009, 161, 878-883. [CrossRef] [PubMed]

24. Cenkci, S.; Yildiz, M.; Cigerci, I.H.; Bozdag, A.; Terzi, H.; Terzi, E.S.A. Evaluation of 2,4-D and dicamba genotoxicity in bean seedlings using comet and RAPD assays. Ecotoxicol. Environ. Saf. 2010, 73, 1558-1563. [CrossRef] [PubMed]

25. Cenkci, S.; Yıldız, M.; Ciğerci, I.H.; Konuk, M.; Bozdă̆, A. Toxic chemicals-induced genotoxicity detected by random amplified polymorphic DNA (RAPD) in bean (Phaseolus vulgaris L.) seedlings. Chemosphere 2009, 76, 900-906. [CrossRef] [PubMed]

26. Abumourad, I.M.K.; Hanna, M.I.; Girgis, S.M. Genotoxicity assessment of ammonia in cultured Oreochromis niloticus using RAPD assay. J. Genet. Eng. Biotechnol. 2012, 10, 209-212. [CrossRef]

27. Aksakal, O.; Erturk, F.A.; Sunar, S.; Bozari, S.; Agar, G. Assessment of genotoxic effects of 2,4dichlorophenoxyacetic acid on maize by using RAPD analysis. Ind. Crops Prod. 2013, 42, 552-557. [CrossRef]

28. Cho, M.H.; No, H.K.; Prinyawiwatkul, W. Chitosan treatments affect growth and selected quality of sunflower sprouts. J. Food Sci. 2008, 73, 70-77. [CrossRef]

29. Baczek-Kwinta, R.; Sala, A. What the antioxidant activity of sprouts depends on? Oxid. Commun. 2012, 4, 990-1000.

30. Niroula, A.; Khatri, S.; Khadka, D.; Timilsina, R. Total phenolic contents and antioxidant activity profile of selected cereal sprouts and grasses. Int. J. Food Prop. 2019, 22, 427-437. [CrossRef]

31. Zou, T.; Xu, N.; Hu, G.; Pang, J.; Xu, H. Biofortification of soybean sprouts with zinc and bioaccessibility of zinc in the sprouts. J. Sci. Food Agric. 2013, 94, 3053-3060. [CrossRef]

32. Beltrami, M.; Rossi, D.; Baudo, R. Phytotoxicity assessment of lake Orta sediments. Aquat. Ecosyst. Health Manag. 1999, 2, 391-401. [CrossRef]

33. Gruszewska-Kossowska, A.; Baran, A. Concentration and health risk assessment of nitrates in vegetables from conventional and organic farming. Hum. Ecol. Risk Assessm. Int. J. 2017, 23, 727-740. [CrossRef]

34. USEPA (United States Environmental Protection Agency). Regional Screening Levels (RSLs)—Generic Tables. Risk Based Screening Table. Composite Table: Summary Tab 0615; USEPA: Washington, DC, USA, 2019. Available online: https://www.epa.gov/risk/regional-screening-levels-rsls-generic-tables (accessed on 1 February 2019). 
35. Pieroni, A.; Janiak, V.; Durr, C.M.; Ludek, S.E.; Trachsel, M.; Heinrich, M. In vitro antioxidant activity of non-cultivated vegetables of ethnic Albanians in Southern Italy. Phytother. Res. 2002, 16, 467. [CrossRef]

36. Simlat, M.; Ptak, A.; Kula, A.; Orzeł, A. Assessment of genetic variability among raspberry accessions using molecular markers. Acta Sci. Pol. Hortorum Cultus 2018, 17, 61-72. [CrossRef]

37. Mubarak, A.E. Nutritional composition and antinutritional factors of mung bean seeds (Phaseolus aureus) as affected by some home traditional processes. Food Chem. 2005, 89, 489. [CrossRef]

38. Wu, X.; Gu, L.; Holden, J.; Gebhardt, S.E.; Beecher, G.; Prior, R.L. Development of a database for total antioxidant capacity in foods: A preliminary study. J. Food Compos. Anal. 2004, 17, 407. [CrossRef]

39. Pitsavos, C.; Panagiotakos, D.B.; Tzima, N.; Chrysohoou, C.; Economo, M.; Zampelas, U.A.; Stefanadis, C. Adherence to the mediterranean diet is associated with total antioxidant capacity in healthy adults: The ATTICA study. Amer. J. Clin. Nutr. 2005, 82, 694. [CrossRef]

40. Issa, A.Y.; Volate, S.R.; Wargovich, M.J. The role of phytochemicals in inhibition of cancer and inflammation: New directions and perspectives. J. Food Compos. Anal. 2006, 19, 405. [CrossRef]

41. Gan, R.Y.; Lui, W.-Y.; Wu, K.; Chan, C.-L.; Dai, S.-H.; Sui, Z.-Q.; Corke, H. Bioactive compounds and bioactivities of germinated edible seeds and sprouts: An updated review. Trends Food Sci. Technol. 2017, 59, 1-14. [CrossRef]

42. Reichman, S.M. The Responses of Plants to Metal Toxicity: A Review Focusing on Copper, Manganese and Zinc; Australian Minerals \& Energy Environment Foundation: Melbourne, Australia, 2002; ISBN 1-876205-13-X2002.

43. Cruz, J.M.; Lopes, P.R.M.; Montagnolli, R.N.; Tamada, I.S.; Silva, N.M.; Bidoia, E.D. Toxicity assessment of contaminated soil using seeds as bioindicators. J. Appl. Biotechnol. Rep. 2013, 1. [CrossRef]

44. Sinclair, S.A.; Krämer, U. The zinc homeostasis network of land plants. BBA Mol. Cell Res. 2012, 1823, 1553-1567. [CrossRef] [PubMed]

45. Ward, M.B.; Scheitler, A.; Yu, M.; Senft, L.; Zillmann, A.S.; Gorden, J.D.; Schwartz, D.D.; Ivanović-Burmazović, I.; Goldsmith, C.R. Superoxide dismutase activity enabled by a redox-active ligand rather than metal. Nat. Chem. 2018, 10, 1207-1212. [CrossRef] [PubMed]

46. Sankar, D.; Sambandam, G.; Rao, M.R.; Pugalendi, K.V. Modulation of blood pressure lipid profiles and redox status in hypertensive patients taking different edible oils. Clin. Chim. Acta 2005, 355, 97-104. [CrossRef] [PubMed]

47. Available online: https://www.nik.gov.pl/aktualnosci/nik-o-dopuszczaniu-do-obrotu-suplementow-diety. html (accessed on 10 February 2017).

48. Gao, Y.; Yang, F.; Liu, J.; Xie, W.; Zhang, L.; Chen, Z.; Peng, Z.; Ou, Y.; Yao, Y. Genome-Wide Identification of Metal Tolerance Protein Genes in Populus trichocarpa and Their Roles in Response to Various Heavy Metal Stresses. Int. J. Mol. Sci. 2020, 21, 1680. [CrossRef] [PubMed] 